\title{
Oligogalacturonide-Mediated Induction of a Gene Involved in Jasmonic Acid Synthesis in Response to the Cell-Wall-Degrading Enzymes of the Plant Pathogen Erwinia carotovora
}

\author{
Cecilia Norman, ${ }^{1}$ Sabina Vidal, ${ }^{1}$ and E. Tapio Palva ${ }^{2}$ \\ ${ }^{1}$ Department of Plant Biology, Uppsala Genetic Center, Swedish University of Agricultural Sciences, Box \\ 7080, S-750 07 Uppsala, Sweden; ${ }^{2}$ Department of Biosciences, Division of Genetics, University of Hel- \\ sinki, Box 56, FIN-00014, Helsinki, Finland \\ Accepted 22 March 1999.
}

\begin{abstract}
Identification of Arabidopsis thaliana genes responsive to plant cell-wall-degrading enzymes of Erwinia carotovora subsp. carotovora led to the isolation of a cDNA clone with high sequence homology to the gene for allene oxide synthase, an enzyme involved in the biosynthesis of jasmonates. Expression of the corresponding gene was induced by the extracellular enzymes from this pathogen as well as by treatment with methyl jasmonate and short oligogalacturonides (OGAs). This suggests that OGAs are involved in the induction of the jasmonate pathway during plant defense response to $E$. carotovora subsp. carotovora attack.
\end{abstract}

Additional keyword: elicitors.

Erwinia carotovora subsp. carotovora and related soft-rot Erwinia spp. constitute one of the most important groups of plant-pathogenic bacteria affecting a wide range of plant species (Pérombelon and Kelman 1980). The virulence of these bacteria is correlated with the ability to produce and secrete a large array of cell-wall-degrading enzymes, including pectinases, cellulases, and proteases, that macerate plant tissue and release nutrients for bacterial growth (Collmer and Keen 1986; Kotoujansky 1987; Pirhonen et al. 1991). These enzymes, in particular pectinases, appear to play a dual role in the interaction between E. carotovora subsp. carotovora and plants; besides being the main virulence determinants of the pathogen they also induce defense responses in plants (Davis et al. 1984; Palva et al. 1993; Vidal et al. 1997, 1998). Inoculation of Arabidopsis thaliana plants with E. carotovora subsp. carotovora results in the development of soft-rot symptoms that can be reproduced by treatment of plants with culture filtrates (CF) from E. carotovora subsp. carotovora containing the secreted plant cell-wall-degrading enzymes of the pathogen. Treatment with CF has also been shown to induce the expression of a number of previously characterized,

Corresponding author: E. Tapio Palva; Fax: +358-9-708 590 76; E-mail: tapio.palva@helsinki.fi defense-related genes in A. thaliana (C. Norman, S. Vidal, and E. T. Palva, unpublished).

To elucidate the $A$. thaliana defense response to $E$. carotovora subsp. carotovora, we wanted to identify new CFinduced genes. The mRNA differential display (Liang and Pardee 1992) was employed to identify such genes. Differences in mRNA populations from untreated (control) and CFtreated plants were characterized in A. thaliana ecotype C24. A 421-bp cDNA fragment present in higher amounts in CFtreated samples was isolated (Fig. 1A), cloned, sequenced, and used as a probe in RNA-gel blot hybridization experiments to confirm the differential expression pattern (Fig. 1B). The cDNA fragment apparently corresponded to a gene that was transiently induced upon CF treatment. A search in data bases revealed that the nucleotide sequence of the cDNA fragment was identical to bases 1230 to 1651 of an A. thaliana sequence identified as an expressed sequence tag (TC14169, TIGR data base; The Institute for Genomic Research, Rockville, MD). The deduced amino acid sequence of this gene shows extensive similarity to allene oxide synthase (AOS) (EC 4.2.1.92, hydroperoxide dehydratase), an enzyme involved in the biosynthesis of jasmonates (Vick and Zimmerman 1987). Alignment of the deduced amino acid sequence of the isolated AOS-like gene (designated Ataol) with other AOS proteins showed $46 \%$ sequence identity to a previously identified A. thaliana AOS (Laudert et al. 1996) and 58, 47 , and $48 \%$ amino acid identity when compared with the pepper, guayule, and flaxseed AOS, respectively. Figure 1C shows the alignment of partial amino acid sequence of Ataol with other known plant AOS sequences. Highly conserved regions such as a heme-binding domain and an oxygenbinding pocket characteristic of cytochrome P450 enzymes and present in all known AOS are also evident in Ataol (boxed). This suggests that Ataol encodes a novel, AOS-like enzyme from $A$. thaliana.

AOS is the first enzyme after lipoxygenase in the biosynthetic pathway of jasmonates. Jasmonates originate from linolenic acid via the inducible octadecanoid pathway consisting of several enzymatic steps (Mueller 1997). AOS 
catalyzes the conversion of fatty acid hydroperoxides to unstable allene epoxides (Song and Brash 1991), which are converted into the jasmonate precursor 12-oxophytodienoic acid through the action of allene oxide cyclase. Jasmonates constitute a large family of compounds, of which jasmonic acid (JA) and its methyl ester, methyl jasmonate (MeJA) are the major physiologically active substances (Sembdner and Parthier 1993). Jasmonates are produced in plants upon wounding (Creelman et al. 1992), elicitor treatment (Gundlach et al. 1992; Doares et al. 1995), and pathogen attack (Penninckx et al. 1996).

Enzymes involved in jasmonate biosynthesis can be induced by elicitors of jasmonate production as well as by JA itself. For example, lipoxygenases have been shown to be induced by wounding, pathogen attack, or direct treatment with exogenous MeJA in A. thaliana (Bell and Mullet 1993; Melan et al. 1993). Similarly, the previously identified A. thaliana AOS was shown to be induced by wounding (Laudert et al. 1996).

To characterize the expression pattern of Ataol, we analyzed the temporal mRNA accumulation for this gene by RNA-gel blot hybridization after treatment of A. thaliana plants with $\mathrm{CF}$ or MeJA, or by wounding. Accumulation of the Ataol transcript was compared with the induction patterns of the previously isolated $A$. thaliana AOS gene (Aos) and two other $\mathrm{CF}$-induced genes in A. thaliana, encoding a vegetative storage protein (Atvsp) and a hevein-like protein ( $\mathrm{Hel}$ ). Atvsp has previously been shown to be induced by MeJA and wounding (Berger et al. 1995) whereas $\mathrm{Hel}$ has been shown to be upregulated by ethylene and turnip crinkle virus infection (Potter et al. 1993). Therefore, these genes were used as markers for the jasmonate and ethylene pathways, respectively.

As seen in Figure 2, CF treatment resulted in accumulation of all four mRNAs studied. Transcript accumulations of Ataol, Aos, and Atvsp showed similar patterns in response to $\mathrm{CF}$ treatment. The three transcripts accumulate within 3 to $6 \mathrm{~h}$ after treatment, reaching maximum levels within 9 to $12 \mathrm{~h}$ and decreasing to almost control levels 24 to $48 \mathrm{~h}$ after treatment. In contrast, induction of the ethylene-responsive gene $\mathrm{Hel}$ by $\mathrm{CF}$ was observed $3 \mathrm{~h}$ after treatment with $\mathrm{CF}$ and continued to increase until $24 \mathrm{~h}$. Forty-eight hours after treatment a de-
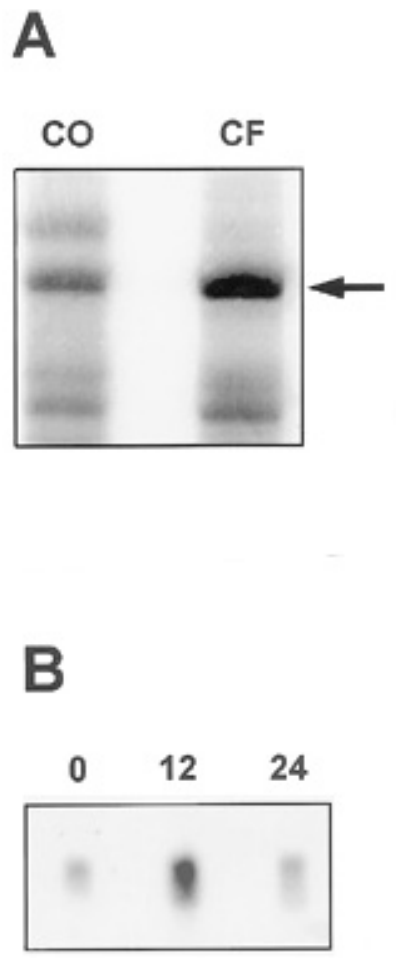

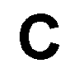

Ataol
Pepper
Arabidopsis
flax seed
guayule

a

LFVLGFNAYGGFSVFLPSLIGRITGDNSG-LQERIRTEVR-RV-C 339 LFILGFNAFGGFTIFLPTLLGNLGDEKNAEMQEKLRKEVREKV - G 328 s LFATSFNTWGGMKILF PNMVKRIGPG-GHQVHNRLAEEIRSVIKS 357 LFAVCFNSWGGFNILFPSLMKWIGRA-GLELHTKLAQEIRSAIQS 376 LFAVCFNTFGGVMILF PNTLKWIGVA-GENLHTQLAEEIRGAIKS 313 $\star \star \star . * \ldots * \ldots \ldots * \ldots$. b

Ataol GSGSDENFKTVNEMELVKSVVYETLRFNPPVPLQPARARKDFQIS 384 Pepper TNQENLSFESVKEMELVQSFVYESLRLSPPVPSQYARARKDFMLS 373 Arabidopsis NG-GELTMGAIEKOMELTKSVVYECLRFEPPVTAQYGRAKKDLVIE 401 flax seed TGGGKVTMAAMEQMPLMKSVVYETLR IEPPVALQYGKAKKDFILE 421 guayule YGDGNVTLEAIEOMPLTKSVYYSLRIEPPVPPQYGKAKSNFTIE 358

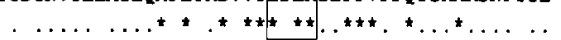

Ataol SHDAVFEVKKGELLCGYQPLVMRDANVFDEPEEFKPDRYVGETGS 429 Pepper SHDSVYIKKGELLCGYQPLVMKDPKVFDEPEKFMLERFTKEKGK 418 Arabidopsis SHDAAFKVKAGEMLYGYQPLATRDPKIFDRADEFVPERFVGEEGE 446 flax seed SHEAAYQVKGEMLFGYQPFATKDPKIFDRPEEFVADRFVG-GV 465 guayule SHDATFEVKKGEMLFGYQPFATKDPKVFDRPEEFVPDRFVGD-GE 402 $\star \star \ldots \ldots *^{* * * * \star * *}, \ldots *^{\star} \ldots * * \ldots * \ldots * \ldots *$ C

Ataol ELLNYLYWSNGPQTGTPSASNKQCAAKDIVTLTASLLVADLFLRY $\mathbf{4 7 4}$ Pepper BLLNYLFWSNGPQTGSPTESNKQCAAXDAVTLTASLIVAYIFQKY 463 Arabidops is KLLRHVLWSNGPETETPTVGNKQCAGKDFWULARLFVIEIFRRY 491 flax seed KLMEYVWWNGPETETPSVANXOCAGKDFVMMARLFVVLFRRY 510 guayule ALLKYVWWSNGPETESPTVENXOCAGKDFVVITRLFVIELFRRY 447

Fig. 1. Identification of an Arabidopsis thaliana cDNA induced upon treatment with culture filtrates from Erwinia carotovora subsp. carotovora. A, A. thaliana ecotype C24 plants were grown axenically for 3 weeks on sterile MS-2 medium (Murashige and Skoog 1962) in a Conviron growth chamber at $22^{\circ} \mathrm{C}$ with a 16-h light regime (120 to $\left.170 \mu \mathrm{E} \mathrm{s}^{-1} \mathrm{~m}^{-2}\right)$. Plants were sprayed with $1 \mathrm{ml}$ of culture filtrate (CF) from E. carotovora subsp. carotovora SCC3193, prepared as previously described (Vidal et al. 1998), and leaf samples corresponding to 12 plants were harvested $12 \mathrm{~h}$ after treatment. Total RNA was prepared from treated (CF) and untreated control (CO) plants as previously described (Vidal et al. 1998) and RNA samples were analyzed by mRNA differential display. Equal amounts of RNA were ensured by spectrophotometrical measurement of OD at 260 nm. A differentially expressed band corresponding to a 421-bp cDNA fragment, indicated with the arrow, was amplified by polymerase chain reaction (PCR) with the $\mathrm{T}_{12} \mathrm{MC}$ anchored primer and the AP-2 random primer from the RNAmap kit (GenHunter, Brookline, NA) and cloned into the pCRII-vector (Invitrogen, San Diego, CA). $\mathbf{B}$, A. thaliana plants grown as described in A were sprayed with $1 \mathrm{ml}$ of CF and leaf samples corresponding to 12 plants were harvested at the indicated time points (hours). Total RNA was isolated and poly A $^{+}$RNA was purified from each sample with oligo dT Dynabeads (Dynal, Oslo, Norway) and analyzed by RNA-gel blot hybridizations. Poly $\mathrm{A}^{+}$RNA (250 ng) was separated on formaldehyde-agarose gels, transferred to nylon membranes, and hybridized to a ${ }^{32} \mathrm{P}$-labeled probe corresponding to the isolated cDNA fragment. C, Alignment of specific regions (a, b, and c) of several known plant allene oxide synthases (AOSs). The deduced amino acid sequence of Ataol (accesssion no. TC14169) was aligned to AOS sequences from pepper (accesssion no. U51676), A. thaliana (accesssion no. X92510), flax seed (accesssion no. P48417), and guayule (accesssion no. A56377). Boxed are an oxygen-binding pocket ( $\mathrm{a}$ and $\mathrm{b}$ ) and a heme-binding domain (c) characteristic of cytochrome P450 enzymes. Identical residues $(*)$; similar residues $(\bullet)$. 
crease in transcript accumulation was evident. Treatment with MeJA or wounding resulted in a strong induction of Ataol, Aos, and Atvsp transcripts whereas a very weak or no induction of $\mathrm{Hel}$ was observed. However, the pattern of induction differed between the Ataol, Aos, and Atvsp genes in response to MeJA or wounding. The rapid transcript accumulation of Aos reached its highest levels within $3 \mathrm{~h}$ after MeJA treatment and within $1 \mathrm{~h}$ after wounding, then started to decline by $6 \mathrm{~h}$ after treatment. In comparison, the Atvsp gene was induced within $3 \mathrm{~h}$ of either treatment and the high level of expression was maintained for at least $12 \mathrm{~h}$. A third pattern of expression in response to MeJA or wounding was seen for the Ataol transcript. Accumulation of Ataol transcripts started $3 \mathrm{~h}$ after treatment, reached maximum levels 9 to $12 \mathrm{~h}$ after treatment and rapidly declined to background levels at $24 \mathrm{~h}$. In conclusion, both the Ataol and Aos genes are responsive to all three treatments although they show different induction patterns. An interesting observation is that the expression of the Ataol gene showed a similar induction pattern after treatment with $\mathrm{CF}$ or MeJA. This differed clearly from the induction of the Aos gene, which showed a similar induction pattern after wound or MeJA treatments. Furthermore, Ataol was induced by $\mathrm{CF}$ to a higher extent than by wounding, while Aos was found to be more responsive to wounding than to $\mathrm{CF}$. Taken together, these results suggest that Ataol could be pathogen regulated, while Aos may represent a more wound-responsive gene.

The data provided in Figure 2 suggest that the induction pattern of Ataol seen in CF-treated plants could be mediated

CF

MeJa

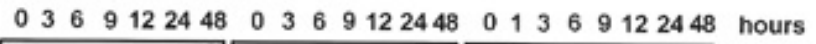

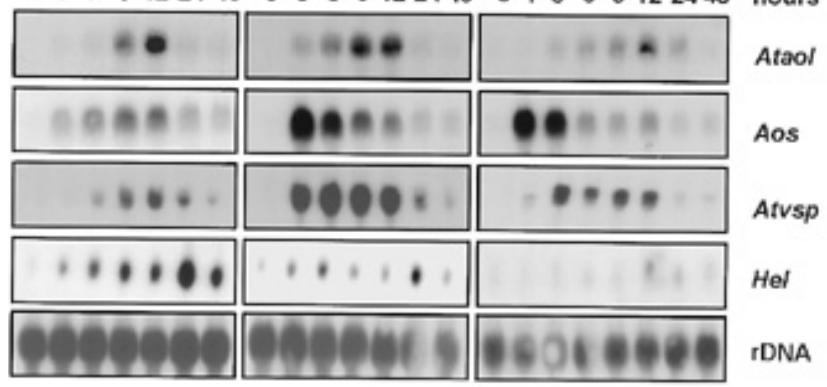

Fig. 2. Accumulation of Ataol, Ataos, Hel, and Atvsp transcripts after treatment with culture filtrates from Erwinia carotovora subsp. carotovora, methyl jasmonate, and wounding. Arabidopsis thaliana plants were sprayed with $1 \mathrm{ml}$ of culture filtrates $(\mathrm{CF})$ from $E$. carotovora subsp. carotovora. Treatments with methyl jasmonate (MeJA) were done by placing a cotton stick containing $46 \mathrm{nmol}$ of MeJA (Bedoukian Research, Danbury, CT) diluted in $96 \%$ ethanol, in a $300-\mathrm{ml}$ jar. Wounding was done by crushing the leaves with forceps. Leaf samples corresponding to 12 plants were harvested at the indicated time points; total RNA was isolated and analyzed by RNA-gel blot hybridizations. Ten micrograms of RNA was separated on formaldehyde-agarose gels, transferred to nylon membranes, and hybridized to the following ${ }^{32} \mathrm{P}$ labeled probes: the isolated 421-bp cDNA fragment corresponding to Ataol, the polymerase chain reaction (PCR)-generated DNA fragments corresponding to bases 131 to 595 from the cDNA sequence of an $A$. thaliana hevein-like gene $(\mathrm{Hel})$ (Potter et al. 1993), to bases 3 to 236 of the clone ATTSO751 (Höfte et al. 1992) encoding an A. thaliana vegetative storage protein acid phosphatase (Atvsp), and to bases 379 to 854 from the cDNA sequence of the previously isolated A. thaliana allene oxide synthase gene (Aos) (Laudert et al. 1996). To ensure equal loading of the RNA samples the filters were hybridized with a probe against ribosomal RNA. by the recognition of signals from the pathogen leading to the induction of genes coding for enzymes in the octadecanoid pathway. At the same time, treatment with MeJA could lead to a feedback amplification of JA synthesis through the induction
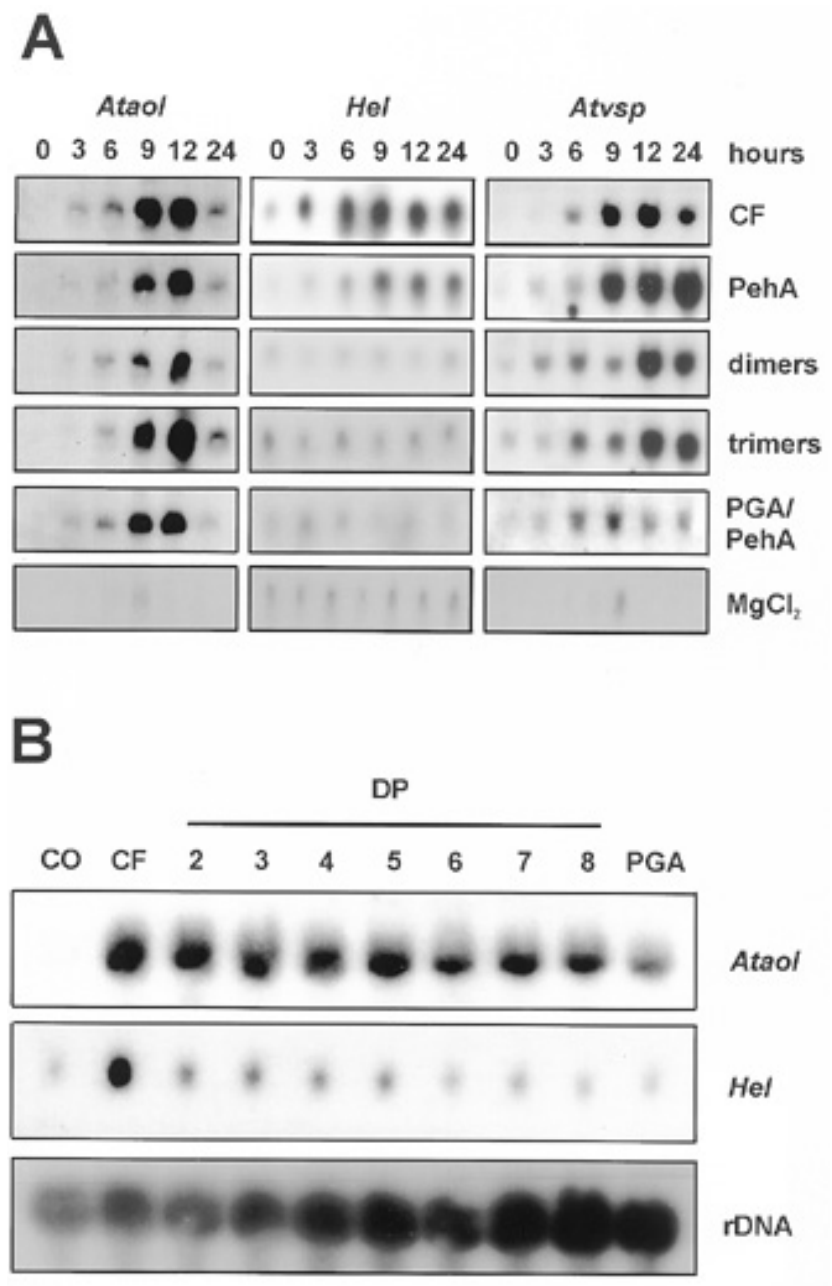

Fig, 3. Expression of Ataol, Atvsp, and Hel upon treatment with short oligogalacturonides. A, Time courses of mRNA accumulation for Ataol, Atvsp, and $\mathrm{Hel}$ were analyzed by RNA-gel blot hybridizations after Arabidopsis thaliana plants were sprayed with $1 \mathrm{ml}$ of the following: culture filtrate from Erwinia carotovora subsp. carotovora (CF), the PehA endopolygalacturonase from E. carotovora subsp. carotovora with an activity similar to that present in the CF (7 units per $\mathrm{ml}$ ) (one unit = amount of enzyme necessary to produce $0.1 \mu \mathrm{mol}$ of glucose equivalent per hour), prepared as previously described (Vidal et al. 1998), $0.1 \mathrm{mM}$ di-galacturonic acid (dimers), $0.1 \mathrm{mM}$ tri-galacturonic acid (trimers), $0.5 \%$ polygalacturonic acid digested during $30 \mathrm{~min}$ with $7 \mathrm{U}$ of PehA and later autoclaved (PGA/PehA), and $10 \mathrm{mM} \mathrm{MgCl}_{2}$. PGA, dimers, and trimers were purchased from Sigma (St. Louis, MO). Ten micrograms of total RNA was hybridized to ${ }^{32} \mathrm{P}$-labeled probes corresponding to Ataol, Atvsp, and $\mathrm{Hel}$ as described in the legend of Figure 2. B, Transcript accumulation of Ataol and $\mathrm{Hel}$ was analyzed by RNA-gel blot experiments after $A$. thaliana plants were sprayed with $1 \mathrm{ml}$ of the following: water control $(\mathrm{CO})$, culture filtrate from $E$. carotovora subsp. carotovora $(\mathrm{CF})$, oligogalacturonides at a concentration of $0.1 \mathrm{mM}$ with a degree of polymerization (DP) ranging from 2 to 8 (kindly provided by Sean D. Simpson, The Plant Laboratory, Department of Biology, University of York, UK), and $0.5 \%$ PGA. Treatments were done for $10 \mathrm{~h}$. Ten micrograms of total RNA was hybridized to ${ }^{32} \mathrm{P}$-labeled probes corresponding to Ataol, Atvsp, and Hel. To ensure equal loading of the RNA samples the filters were hybridized with a probe against ribosomal RNA. 
of Ataol. This feedback amplification has been shown for Aos (Laudert and Weiler 1998) and for lipoxygenase, another enzyme involved in JA synthesis (Melan et al. 1993). Since JA appears to be necessary for both the wound and pathogen defense response of plants (Howe et al. 1996; Vijayan et al. 1998), it is conceivable that different AOSs might modulate the increase in jasmonate levels in response to different stimuli such as pathogens or wounding.

The mechanism by which extracellular enzymes of $E$. carotovora subsp. carotovora induce defense responses in plants has been proposed to involve the release of oligogalacturonide (OGA) elicitors from plant cell wall pectin (Davis et al. 1984; Yang et al. 1992; Palva et al. 1993). OGAs induce a wide variety of responses in plants, which in most cases depend on the degree of polymerization (DP). These responses include rapid changes at the cell surface such as phosphorylation of plasma membrane-associated proteins (Farmer et al. 1991; Reymond et al. 1995), accumulation of phytoalexins and lignification (Ebel and Cosio 1994), induction of proteinase inhibitors (Ryan 1988), JA production (Doares et al. 1995), and the biosynthesis of ethylene (Tong et al. 1986). Although most reports show that OGAs with a DP of 9 and greater induce defense responses against pathogens (Darvill et al. 1992), smaller oligomers have also been shown to activate defenses in plants. For example, OGAs with a DP 2 to 4 have been shown to induce resistance against $E$. carotovora subsp. atroseptica in potato (Weber et al. 1996; Wegener et al. 1996). Furthermore, OGAs with a DP less than 8 can trigger ethylene production (O'Donnell et al. 1996; Simpson et al. 1998), and the accumulation of proteinase inhibitors in tomato (Moloshok et al. 1992; O'Donnell et al. 1996).

Pectolytic enzymes from several Erwinia spp. have been shown to digest the polygalacturonate from plant cell walls into short uronate oligomers, predominantly dimers and trimers (Forrest and Lyon 1990; Preston et al. 1992; Bartling et al. 1995). This prompted us to study the role of short OGAs in the CF-induced expression of plant defense-related and JAresponsive genes. Transcript accumulation of Ataol, Atvsp, and $\mathrm{Hel}$ was analyzed by RNA-gel blot hybridizations after treatment of plants with $\mathrm{CF}$, the PehA endopolygalacturonase (one of the major pectolytic enzymes from E. carotovora subsp. carotovora) (Saarilahti et al. 1990), dimers, trimers of polygalacturonic acid (PGA), and PehA-digested polygalacturonic acid (PGA/PehA) (Fig. 3A). The results clearly indicate that dimers and trimers of PGA as well as the digested PGA induce the expression of Ataol and Atvsp with induction levels and kinetics similar to those resulting from treatment with $\mathrm{CF}$ or PehA. In contrast, although $\mathrm{Hel}$ was strongly induced by $\mathrm{CF}$ or PehA, very low or no induction of $\mathrm{Hel}$ gene expression was observed upon treatment with short OGAs. As mentioned above, OGAs with a DP of 8 and shorter have been shown to induce ethylene production in tomato plants by 30 min after treatment (O'Donnell et al. 1996; Simpson et al. 1998). If this is true for A. thaliana, treatment with these short OGAs should trigger the expression of ethylene-responsive genes such as $\mathrm{Hel}$. To elucidate the role of the DP of OGAs in $\mathrm{Hel}$ and Ataol expression, we treated plants with OGAs with a DP of 2 to 8 and characterized the induction of $\mathrm{Hel}$ and Ataol by RNA-gel blot hybridization (Fig. 3B). All treatments induced the expression of Ataol and maximum levels of transcript accumulation were observed after treatment with $\mathrm{CF}$ as well as with OGAs with a DP ranging from 2 to 5 . However, accumulation of $\mathrm{Hel}$ transcripts was only marginally induced after treatment with OGAs and did not reach the levels observed upon treatment with $\mathrm{CF}$. Taken together, the results suggest that short OGAs released by the action of pectinolytic enzymes mediate the activation of JAresponsive genes upon E. carotovora subsp. carotovora attack. Application of OGAs with a DP of 4 to 6 to tomato plants through the transpiration stream has been shown to induce ethylene production (Simpson et al. 1998). However, in our system, treatment with short OGAs by spraying $A$. thaliana plants may not lead to a concentration of ethylene high enough to induce expression of the $\mathrm{Hel}$ gene. This suggests that the production of short cell wall fragments is not the only way that hydrolytic enzymes from E. carotovora subsp. carotovora elicit defense responses in plants.

\section{ACKNOWLEDGMENTS}

We wish to thank Sean D. Simpson (The Plant Laboratory, Department of Biology, University of York, UK) for kindly providing the oligogalacturonides. We are grateful to Mona Munter for preparing the plant material. This work was supported by SIDA, the Swedish Council for Forestry and Agricultural Research (SJFR), the Swedish Natural Sciences Research Council (NFR), and the Foundation in the Memory of Oskar and Lili Lamm. E. T. P. is also supported by the Academy of Finland, Biocentrum Helsinki and EU (contract no. ERBIC15-CT96-0908).

\section{LITERATURE CITED}

Bartling, S., Wegener, C., and Olsen, O. 1995. Synergism between Erwinia pectate lyase isoenzymes that depolymerize both pectate and pectin. Microbiology 141:873-881.

Bell, E., and Mullet, J. E. 1993. Characterization of an Arabidopsis lipoxygenase gene responsive to methyl jasmonate and wounding. Plant Physiol. 103:1133-1137.

Berger, S., Bell, E., Sadka, A., and Mullet, J. E. 1995. Arabidopsis thaliana Atvsp is homologous to soybean $V s p A$ and $V s p B$, genes encoding vegetative storage protein acid phosphatases, and is regulated similarly by methyl jasmonate, wounding, sugars, light and phosphate. Plant Mol. Biol. 27:933-942.

Collmer, A., and Keen, N. T. 1986. The role of pectic enzymes in plant pathogenesis. Annu. Rev. Phytopathol. 24:383-409.

Creelman, R. A., Tierney, M. L., and Mullet, J. E. 1992. Jasmonic acid/methyl jasmonate accumulate in wounded soybean hypocotyls and modulate wound gene expression. Proc. Natl. Acad. Sci. USA 89: 4938-4941.

Darvill, A., Augur, C., Bergmann, C., Carlson, R. W., Cheong, J.-J., Eberhard, S., Hahn, M. G., Ló, V.-M., Marfà, V., Meyer, B., Mohnen, D., O'Neill, A. O., Spiro, M. D., van Halbeek, H., York, W. S., and Albersheim, P. 1992. Oligosaccharins - oligosaccharides that regulate growth, development and defence responses in plants. Glycobiology 2: 181-198.

Davis, K. R., Lyon, G. D., Darvill, A. G., and Albersheim, P. 1984. Hostpathogen interactions. XXV. Endopolygalacturonic acid lyase from Erwinia carotovora elicits phytoalexin accumulation by releasing plant cell wall fragments. Plant Physiol. 74:52-60.

Doares, S. H., Syrovets, T., Weiler, E. W., and Ryan, C. A. 1995. Oligogalacturonides and chitosan activate plant defensive genes through the octadecanoid pathway. Proc. Natl. Acad. Sci. USA 92: 4095-4098.

Ebel, J., and Cosio, E. G. 1994. Elicitors of plant defense responses. Int. Rev. Cytol. 148:1-36.

Farmer, E. E., Moloshok, T. D., Saxton, M. J., and Ryan, C. A. 1991. Oligosaccharide signaling in plants. Specificity of oligouronideenhanced plasma membrane protein phosphorylation. J. Biol. Chem. 266:3140-3145. 
Forrest, R. S., and Lyon, G. D. 1990. Substrate degradation pattern of polygalacturonic acid lyase from Erwinia carotovora and Bacillus polymyxa and release of phytoalexin-eliciting oligosaccharides from potato cell walls. J. Exp. Bot. 41:481-488.

Gundlach, H., Müller, M. J., Kutchan, T. M., and Zenk, M. H. 1992. Jasmonic acid is a signal transducer in elicitor-induced plant cell cultures. Proc. Natl. Acad. Sci. USA 89:2389-2393.

Höfte, H., Desprez, T., Amselem, J., Chiapello, H., Caboche, M., Moisan, A., Jourjon, M.-F., Charpenteau, L., Berthomieu, P., Guerrier, D., Giraudat, J., Quigley, F., Thomas, F., Yu, D.-Y., Mache, R., Raynal, M., Cooke, R., Grellet, F., Delseny, M., Parmentier, Y., de Marcillac, G., Gigot, C., Fleck, J., Phillips., G., Axelos, M., Bardet, C., Tremousaygue, D., and Lescure, B. 1992. An inventory of 1152 expressed sequence tags obtained by partial sequencing of cDNAs from Arabidopsis thaliana. Plant J. 4:1051-1061.

Howe, G. A., Lightner, J., Browse, J., and Ryan, C. A. 1996. An octadecanoid pathway mutant (JL5) of tomato is compromised in signaling for defense against insect attack. Plant Cell. 8:2067-2077.

Kotoujansky, A. 1987. Molecular genetics of pathogenesis by soft-rot Erwinias. Annu. Rev. Phytopathol. 25:405-430.

Laudert, D., Pfannschmidt, U., Lottspeich, F., Hollaender-Czytko, H., and Weiler, E. W. 1996. Cloning, molecular and functional characterization of Arabidopsis thaliana allene oxide synthase (CYP 74), the first enzyme of the octadecanoid pathway to jasmonates. Plant Mol. Biol. 31:323-335.

Laudert, D., and Weiler, E. W. 1998. Allene oxide synthase: A major control point in Arabidopsis thaliana octadecanoid signalling. Plant J. 15:675-684.

Liang, P., and Pardee, A. B. 1992. Differential display of eukaryotic messenger RNA by means of the polymerase chain reaction. Science 257:967-971

Melan, M. A., Dong, X., Endara, M. E., Davis, K. R., Ausubel, F. M., and Peterman, T. K. 1993. An Arabidopsis thaliana lipoxygenase gene can be induced by pathogens, abscisic acid, and methyl jasmonate. Plant Physiol. 101:441-450.

Moloshok, T., Pears, G., and Ryan, C. A. 1992. Oligouronide signaling of proteinase inhibitor genes in plants: structure-activity relationships of di- and trigalacturonic acids and their derivatives. Arch. Biochem. Biophys. 294:731-734.

Mueller, M. J. 1997. Enzymes involved in jasmonic acid biosynthesis. Physiol. Plant. 100:653-663

Murashige, T., and Skoog, F. 1962. A revised medium for rapid growth and bioassays with tobacco tissue culture. Physiol. Plant. 15:473-497.

O'Donnell, P. J., Calvert, C., Atzorn, R., Wasternack, C., Leyser, H. M. O., and Bowles, D. J. 1996. Ethylene as a signal mediating the wound response of tomato plants. Science 274:1914-1917.

Palva, T. K., Holmström, K.-O., Heino, P., and Palva, E. T. 1993. Induction of plant defense response by exoenzymes of Erwinia carotovora subsp. carotovora. Mol. Plant-Microbe Interact. 6:190-196.

Penninckx, I. A. M. A., Eggermont, K., Terras, F. R. G., Thomma, B. P. H. J., De Samblanx, G. W., Buchala, A., Metraux, J.-P., Manners, J. M., and Broekaert, W. F. 1996. Pathogen-induced systematic activation of a plant defensin gene in Arabidopsis follows a salicylic acid-independent pathway. Plant Cell 8:2309-2323.

Pérombelon, M. C. M., and Kelman, A. 1980. Ecology of the soft rot Erwinias. Annu. Rev. Phytopathol. 18:361-387.

Pirhonen, M., Saarilahti, H., Karlsson, M.-B., and Palva, E. T. 1991.
Identification of pathogenicity determinants of Erwinia carotovora subsp. carotovora by transposon mutagenesis. Mol. Plant-Microbe Interact. 4:276-283.

Potter, S., Uknes, S., Lawton, K., Winter, A. M., Chandler, D., DiMaio, J., Novitzky, R., Ward, E., and Ryals, J. 1993. Regulation of a heveinlike gene in Arabidopsis. Mol. Plant-Microbe Interact. 6:680-685.

Preston, J. F., III, Rice, J. D., Ingram, L. O., and Keen, N. T. 1992. Differential depolymerization mechanisms of pectate lyases secreted by Erwinia chrysanthemi EC16. J. Bacteriol. 174:2039-2042.

Reymond, P., Grunberger, S., Paul, K., Muller, M., and Farmer, E. E. 1995. Oligogalacturonide defense signals in plants: Large fragments interact with the plasma membrane in vitro. Proc. Natl. Acad. Sci. USA 92:4145-4149.

Ryan, C. A. 1988. Oligosaccharides as recognition signals for the expression of defensive genes in plants. Biochemistry 27:8879-8883.

Saarilahti, H. T., Heino, P., Pakkanen, R., Kalkkinen, N., Palva, I., and Palva, E. T. 1990. Structural analysis of the pehA gene and characterization of its protein product, endopolygalacturonase, of Erwinia carotovora subspecies carotovora. Mol. Microbiol. 4:10371044.

Sembdner, G., and Parthier, B. 1993. The biochemistry and the physiological and molecular actions of jasmonates. Annu. Rev. Plant Physiol. Plant Mol. Biol. 44:569-589.

Simpson, S. D., Ashford, D. A., Harvey, D. J., and Bowles, D. J. 1998 Short chain oligogalacturonides induce ethylene production and expression of the gene encoding aminocyclopropane 1-carboxylic acid oxidase in tomato plants. Glycobiology 8:579-583.

Song, W. C., and Brash, A. R. 1991. Purification of an allene oxide synthase and identification of the enzyme as a cytochrome P-450. Science 253:781-784.

Tong, C. B., Labavitch, J. M., and Yang, S. F. 1986. The induction of ethylene production from pear cell culture by cell wall fragments. Plant Physiol. 81:929-930.

Vick, B. A., and Zimmerman, D. C. 1987. Oxidative systems for modification of fatty acids: The lipoxygenase pathway. Pages 53-90 in: The Biochemistry of Plants. P. K. Stumpf and E. E. Conn, eds. Academic Press, New York.

Vidal, S., Eriksson, A. R. B., Montesano, M., Denecke, J., and Palva, E. T. 1998. Cell wall-degrading enzymes from Erwinia carotovora cooperate in the salicylic acid-independent induction of a plant defense response. Mol. Plant-Microbe Interact. 11:23-32.

Vidal, S., Ponce de León, I., Denecke, J., and Palva, E. T. 1997 Salicylic acid and the plant pathogen Erwinia carotovora induce defense genes via antagonistic pathways. Plant J. 11:115-123.

Vijayan, P., Shockey, J., Levesque, C. A., Cook, R. J., and Browse, J. 1998. A role for jasmonate in pathogen defense of Arabidopsis. Proc. Natl. Acad. Sci. USA 95:7209-7214.

Weber, J., Olsen, O., Wegener, C., and Von Wettstein, D. 1996. Digalacturonates from pectin degradation induce tissue responses against potato soft rot. Physiol. Mol. Plant Pathol. 48:389-401.

Wegener, C., Bartling, S., Olsen, O., Weber, J., and von Wettstein, D. 1996. Pectate lyase in transgenic potatoes confers preactivation of defence against Erwinia carotovora. Physiol. Mol. Plant Pathol. 49: 359-376.

Yang, Z., Cramer, C. L., and Lacy, G. H. 1992 Erwinia carotovora subsp. carotovora pectic enzymes: In planta gene activation and roles in soft-rot pathogenesis. Mol. Plant-Microbe Interact. 5:104-112. 